\title{
Impact of Elastin-Derived Peptide VGVAPG on Matrix Metalloprotease-2 and -9 and the Tissue Inhibitor of Metalloproteinase-1, $-2,-3$ and -4 mRNA Expression in Mouse Cortical Glial Cells In Vitro
}

\author{
Konrad A. Szychowski ${ }^{1}$ (D) Anna K. Wójtowicz ${ }^{2} \cdot$ Jan Gmiński ${ }^{1}$
}

Received: 8 February 2018 /Revised: 13 July 2018 / Accepted: 17 July 2018 / Published online: 30 July 2018

(C) The Author(s) 2018

\begin{abstract}
Degradation products of elastin, i.e. elastin-derived peptides (EDPs), are involved in various physiological and pathological processes. EDPs are detectable in cerebrospinal fluid in healthy people and in patients after ischemic stroke. However, to date, no studies concerning the role of EDP in the nervous system were conducted. Matrix metalloproteinases (MMPs) and tissue inhibitors of metalloproteinases (TIMPs) play important roles during the repair phases of cerebral ischemia, particularly during angiogenesis and reestablishment of cerebral blood flow. Therefore, the aim of this study was to investigate the impact of the specific elastin-derived peptide VGVAPG on Mmp-2, -9 and Timp-1, -2,-3 and -4 mRNA expression in mouse cortical glial cells in vitro. Primary glial cells were maintained in DMEM/F12 without phenol red supplemented with $10 \%$ fetal bovine serum and the cells were exposed to $50 \mathrm{nM}, 1$ and $50 \mu \mathrm{M}$ of the VGVAPG peptide. After 3 and $6 \mathrm{~h}$ of exposition to the peptide, expression of Mmp-2, -9 and Timp-1, -2, -3 and -4 mRNA was measured. Moreover, siRNA gene knockdown, cytotoxicity and apoptosis measurement were included in our experiments, which showed that VGVAPG in a wide range of concentrations exhibited neither proapoptotic nor cytotoxic properties in mouse glial cells in vitro. The peptides enhanced mRNA expression of Timp-2 and Timp3 genes in an elastin-binding protein (EBP)-dependent manner. However, changes in mRNA expression of Mmp-2, Mmp-9 and Timp-4 were partially EBP-dependent. The decrease in mRNA expression of Timp-1 was EBP-independent. However, further studies underlying the VGVAPG peptide's mechanism of action in the nervous system are necessary.
\end{abstract}

Keywords Elastin-derived peptides $\cdot$ VGVAPG $\cdot$ Glial cells $\cdot$ MMP-2 $\cdot$ MMP-9 $\cdot$ TIMPs

\footnotetext{
Highlights

- The VGVAPG peptide in a wide range of concentrations exhibited neither proapoptotic nor cytotoxic properties in mouse astrocytes in vitro

- The VGVAPG peptide enhanced mRNA expression of Timp-2 and

Timp-3 genes in an elastin-binding protein (EBP)-dependent manner

- The VGVAPG peptide's change in the mRNA expression pattern of Mmp-2, Mmp-9 and Timp-4 was partially EBP-dependent

- The VGVAPG peptide's decrease in the mRNA expression of Timp-1 was EDP-independent
}

Electronic supplementary material The online version of this article (https://doi.org/10.1007/s12640-018-9935-x) contains supplementary material, which is available to authorized users.

Konrad A. Szychowski

konrad.szychowski@gmail.com

1 Department of Public Health, Dietetics and Lifestyle Disorders, Faculty of Medicine, University of Information Technology and Management in Rzeszow, Sucharskiego 2, 35-225 Rzeszow, Poland

2 Department of Animal Biotechnology, Faculty of Animal Sciences, University of Agriculture, Redzina 1B, 30-248 Krakow, Poland

\begin{tabular}{ll}
\multicolumn{2}{l}{ Abbreviations } \\
CNS & Central nervous system \\
CSF & Cerebrospinal fluid \\
DMSO & Dimethyl sulfoxide \\
EDPs & Elastin-derived peptides \\
FasR & Fas receptor \\
FBS & Fetal bovine serum \\
LDH & Lactate dehydrogenase \\
PBS & Phosphate-buffered saline \\
ROS & Reactive oxygen species \\
MMP & Matrix metalloprotease \\
TIMP & Tissue inhibitor of metalloproteinase \\
VGVAPG & Val-Gly-Val-Ala-Pro-Gly \\
siRNA & Small interfering RNA \\
EBP & Elastin-binding protein
\end{tabular}

Abbreviations

CNS Central nervous system

CSF Cerebrospinal fluid

DMSO Dimethyl sulfoxide

EDPs Elastin-derived peptides

FasR Fas receptor

FBS Fetal bovine serum

LDH Lactate dehydrogenase

PBS Phosphate-buffered saline

ROS Reactive oxygen species

MMP Matrix metalloprotease

TIMP Tissue inhibitor of metalloproteinase

siRNA Small interfering RNA

Elastin-binding protein 


\section{Introduction}

Elastin is an essential protein in mammalian organisms and provides elasticity to many connective tissues such as the major arteries, lung, cartilage, elastic ligaments and skin. Products of proteolytic degradation of elastin, namely elastin-derived peptides (EDPs), are involved in various physiological and pathological processes (Gmiński et al. 1992, 1993). EDPs are detectable in cerebrospinal fluid (CSF) in healthy people $(6.3 \mathrm{ng} / \mathrm{mL})$ and in patients after ischemic stroke (129.5-205.0 ng/mL) (Nicoloff et al. 2008; Tzvetanov et al. 2008), which suggests involvement of EDPs in pathological conditions and/or the regeneration process. In different physiological and pathophysiological conditions, such as inflammation or atherosclerosis, elastin is prone to proteolytic degradation which frees Val-Gly-Val-Ala-ProGly (VGVAPG)-containing fragments (Lombard et al. 2006; O'Rourke 2007). The VGVAPG (498.58 molecular weight (MW)) hexapeptide is repeated multiple times in elastin molecules and binds to 67-kDa elastin-binding protein (EBP) with high affinity (Blood et al. 1988; Senior et al. 1984). EBP is a catalytically inactive form of beta-galactosidase produced by alternative splicing of the GLB1 gene (Hinek et al. 1993; Skeie et al. 2012). To date, it has been demonstrated that VGVAPG induces diverse biological effects through EBP, depending on the research model. The VGVAPG peptide induced normal human cell proliferations such as fibroblast, monocyte and cancerous, e.g. human astrocytoma (Jung et al. 1998; Senior et al. 1984). Furthermore, the VGVAPG peptide exhibits strong chemotactic properties in the murine lung carcinoma cell line (M27) and facilitates the invasion of human melanoma cells (WM35 and HT168-M1) (Blood et al. 1988; Pocza et al. 2008). In addition to its chemotactic properties, it has been shown that EDPs or the VGVAPG peptide also upregulated the expression of different metalloproteinases (Floquet et al. 2004; Siemianowicz et al. 2010).

Matrix metalloproteinases (MMPs) are a family of zincdependent extracellular matrix-degrading enzymes involved in diverse homeostatic and pathological processes (Agrawal et al. 2008; Crocker et al. 2004). MMP-2 and MMP-9 (gelatinase A and B, respectively) are expressed within the central nervous system (CNS) and perform important normal and pathological functions during development and adulthood (Crocker et al. 2004; Yong et al. 2001). A number of papers show the emerging roles of MMP-2 and MMP-9 and their natural inhibitors, tissue inhibitors of metalloproteinases (TIMPs) in the regulation of astrocytic and neuronal cell death (Cunningham et al. 2005). In addition, MMPs and TIMPs are likely to play important roles during the repair phases of cerebral ischemia, particularly during angiogenesis and reestablishment of cerebral blood flow (Cunningham et al. 2005; Vanmeter et al. 2001; Wang et al. 2014). These processes will have important implications for therapies using MMP inhibitors in stroke (Cunningham et al. 2005). To date, it has been shown that the VGVAPG peptide in concentrations of $100 \mathrm{ng} / \mathrm{mL} \approx 200.57 \mathrm{nM}$ and $200 \mathrm{ng} / \mathrm{mL} \approx 401.14 \mathrm{nM}$ enhances angiogenesis by promoting endothelial cell migration and tubulogenesis through upregulation expression of mRNA of membrane-type matrix metalloprotease-1 (MT1-MMP) and $M M P-2$ (Robinet 2005). A similar result was obtained by Ntayi et al. (2004), who showed that cell culture plates coated with 100.28 or $401.14 \mu \mathrm{M}$ of VGVAPG caused an increase in the expression and activation of MMP-2 and MT1-MMP in two melanoma (M1Dor and M3Da) cell lines. Furthermore, it was shown that adding $200 \mu \mathrm{g} / \mathrm{mL} \approx 401.14 \mu \mathrm{M}$ of the VGVAPG peptide to the culture medium upregulated MMP2, MT1-MMP and TIMP-2 mRNA expression and activity in the human fibrosarcoma (HT-1080) cell line and thus increased invasiveness of HT-1080 cells (Brassart et al. 1998; Donet et al. 2014).

Data concerning the VGVAPG peptide in CNS are very poor and limited to a few publications. So far, it has been demonstrated that $200 \mathrm{nM}$ of the VGVAPG peptide can stimulate dendrite formations in mouse primary neuron culture (Chang et al. 2008). Furthermore, in human glioblastoma multiforme cell lines CB74, CB109 and CB191 and the rat astrocytoma cell line $\mathrm{C} 6$ exposed to $500 \mathrm{ng} / \mathrm{mL} \approx 334.28 \mathrm{nM}$ of the (VGVAPG) ${ }_{3}$ peptide, mRNA expression of $M M P-2$ dramatically increased with very low stimulation of $M M P-9$ (Coquerel et al. 2009). The authors linked this high expression of $M M P-2$ mRNA with an increasing number of migrating cells. Even though EDPs have been detected in ageing brains and different pathologies of the CNS, no studies on EDPs' role on normal glial cells have been conducted so far.

The aim of this study was to investigate the impact of specific elastin-derived peptide Val-Gly-Val-Ala-Pro-Gly (VGVAPG) on matrix metalloprotease-2 and -9 (Mmp-2, -9) and the tissue inhibitor of metalloproteinase-1, $-2,-3$ and -4 (Timp-1, -2, -3 and -4) mRNA expression in mouse cortical glial cells in vitro.

\section{Materials and Methods}

\section{Reagents}

DMEM/F12 1:1 (16-405-CVR) without phenol red was purchased from Corning (Manassas, USA). Trypsin, streptomycin, penicillin, glycerol, CHAPS, HEPES, dithiothreitol (DTT), NaCl, EDTA, calcein AM, Hoechst 33342 and dimethyl sulfoxide (DMSO) were purchased from SigmaAldrich (St. Louis, MO, USA). The substrate for caspase-3 (235400) was purchased from Merck (Darmstadt, Germany). The cytotoxicity detection kit and FastStart Universal Probe Master (Rox) were purchased from ROCHE Applied Science (Mannheim, Germany). The Glb1 gene siRNA (sc-61342) 
was purchased from Santa Cruz Biotechnology (Santa Cruz, CA, USA). The VGVAPG peptide was synthesised by LipoPharm.pl (Gdańsk, Poland). Charcoal/dextran-treated fetal bovine serum (FBS) was purchased from EURx (Gdańsk, Poland). The cDNA reverse transcription kit - High Capacity cDNA - Reverse Transcription Kit and the TaqMan ${ }^{\circledR}$ probes corresponding to specific genes encoding Actb (Mm00607939_s1), Mmp-2 (Mm00439498_m1), Mmp-9 (Mm00442991_m1), Timp-1 (Mm01341361_m1), Timp-2 (Mm00441825_m1), Timp-3 (Mm00441826_m1) and Timp4 (Mm01184417_m1) were obtained from Life Technologies Applied Biosystems (Foster City, CA, USA). Stock solutions of the VGVAPG peptide were prepared in DMSO and were added to DMEM/F12 medium. The final concentration of DMSO in the culture medium was always $0.1 \%$.

\section{Glial Cell Culture}

The experiments were performed on mouse glial cells cell culture isolated from the fetuses (17/18 embryonal day) of pregnant female Swiss mice. Animals were anesthetised with $\mathrm{CO}_{2}$ vapour and killed by cervical dislocation. All procedures were approved by a Bioethics Commission (no. 46/2014, First Local Ethical Committee on Animal Testing at the Jagiellonian University in Krakow), as compliant with European Union law. After isolation and digestion process, cells were centrifuged and the pellet was suspended in DMEM/F12 1:1 without phenol red supplemented with 10\% fetal bovine serum (FBS), $100 \mathrm{U} / \mathrm{mL}$ penicillin, $0.10 \mathrm{mg} / \mathrm{mL}$ streptomycin and $250 \mathrm{ng} / \mathrm{mL}$ amphotericin B with modifications of the previously described method (Blomstrand and Giaume 2006; Vitvitsky et al. 2006; Wang et al. 1998), [see different glial culture media and the techniques review in Saura (2007)]. The cells were seeded at a density of $20 \times$ $10^{6}$ cells $/ 75 \mathrm{~cm}^{2}$ in culture flasks. The cultures of the glial cells were maintained at $37{ }^{\circ} \mathrm{C}$ in atmosphere containing $5 \%$ $\mathrm{CO}_{2}$. In the logarithmic phase, after reaching $90 \%$ confluence, the cells were collected and frozen in liquid nitrogen. This procedure kills neurons in culture and leaves the glial cells, which allows to collect a large number of cell banks and to store cells for further research. Before the experiment, the cells were thawed and seeded in culture flasks and cultured for approximately a week to reach $80-90 \%$ confluence. Then, the cells were trypsinised with $0.25 \%$ trypsin $/ 0.05 \%$ EDTA and passaged on to an experimental plate.

\section{Lactate Dehydrogenase Cytotoxicity Assay}

An increase in the amount of dead or plasma membranedamaged cells results in an increase in lactate dehydrogenase (LDH) release in the culture medium (Koh and Choi 1987). After 24 and $48 \mathrm{~h}$ of treating the cells with a medium containing $100 \mathrm{pM}-100 \mu \mathrm{M}$ of the VGVAPG peptide, $100 \mu \mathrm{L}$ of the culture supernatants was collected and incubated in a reaction mixture from the kit according to the manufacturer's protocol. After $30 \mathrm{~min}$, the reaction was stopped by adding $1 \mathrm{~N} \mathrm{HCl}$ and absorbance at a wavelength of $490 \mathrm{~nm}$ was measured using the FilterMax F5 Multi-Mode microplate reader (Molecular Devices, Corp., Sunnyvale, CA, USA).

\section{Caspase-3 Activity}

Caspase-3 activity was used as a marker of cell apoptosis and was assessed according to Nicholson et al. (1995). Cultured glial cells were lysed using lysis buffer (50 mM HEPES, $\mathrm{pH}$ 7.4, $100 \mathrm{mM} \mathrm{NaCl}, 0.1 \%$ CHAPS, $1 \mathrm{mM}$ EDTA, $10 \%$ glycerol and $10 \mathrm{mM}$ DTT) in $10{ }^{\circ} \mathrm{C}$ for $10 \mathrm{~min}$. After initial incubation, the lysates were incubated with caspase- 3 substrate Ac-DEVD-pNA at $37{ }^{\circ} \mathrm{C}$. Cells treated with $1 \mu \mathrm{M}$ staurosporine were used as a positive control (result not shown). After $30 \mathrm{~min}$, absorbance of the lysates at $405 \mathrm{~nm}$ was measured using a microplate reader (FilterMax F5 MultiMode microplate reader). The amount of colorimetric product was continuously monitored for $120 \mathrm{~min}$.

\section{Hoechst 33342 and Calcein AM Staining}

Hoechst 33342 and calcein AM staining were used to determine DNA fragmentation and metabolic activity and/or cell viability of cultured glial cells. Mouse primary glial cells were exposed to $1 \mu \mathrm{M}$ of the VGVAPG peptide and the cells were cultured for an additional $24 \mathrm{~h}$. After this period, glial cells were stained according to previously described method (Szychowski et al. 2015). The cells were washed with phosphate-buffered saline (PBS) and exposed to Hoechst 33342 and calcein AM diluted in DMEM/F12 1:1 and added to the glial cells culture at a final concentration of 10 and $4 \mu \mathrm{M}$, respectively. The cells were incubated for $15 \mathrm{~min}$ in an atmosphere of $5 \%$ and $\mathrm{CO}_{2}$ at $37^{\circ} \mathrm{C}$, washed one time in PBS and visualised by using a fluorescence microscope (LSM 700, ZEISS). Cell fluorescence in microphotographs was quantified by densitometry using Image J $1.50 \mathrm{~b}$ software (National Institutes of Health, Bethesda, USA).

\section{siRNA Gene Silencing Procedure}

Glb1 siRNA was used to inhibit Glb1 gene expression in mouse primary glial cells. siRNA was applied for $7 \mathrm{~h}$ at a final concentration of $50 \mathrm{nM}$ in antibiotic-free medium containing the siRNA transfection reagent INTERFERin, according to previously described method (Szychowski et al. 2017). The effectiveness of $G l b 1$ mRNA silencing with the use of $50 \mathrm{nM}$ specific siRNA was verified by measuring the mRNA levels. Cells were treated with $1 \mu \mathrm{M}$ of the VGVAPG peptide and after 3 and $6 \mathrm{~h}$, expression of genes encoding Mmp-2, Mmp-9, Timp-1, Timp-2, Timp-3 and Timp-4 was determined. 


\section{Real-Time PCR Analysis of mRNAs Specific to Genes Encoding Mmp-2, Mmp-9, Timp-1, Timp-2, Timp-3 and Timp-4}

For the real-time PCR assay, glial cells were seeded on 12well plates and initially cultured for $24 \mathrm{~h}$. After 3 and $6 \mathrm{~h}$ of exposure to $50 \mathrm{nM}$ and 1 and $50 \mu \mathrm{M}$ of VGVAPG, samples of total RNA were extracted from glial cells according to the manufacturer's protocol based on a previously described method (Szychowski et al. 2017). After siRNA transfection, the procedure was performed after 3 and $6 \mathrm{~h}$ of exposure for a concentration of $1 \mu \mathrm{M}$ of VGVAPG. The RNA quality and quantity were determined spectrophotometrically at $260 \mathrm{~nm}$ and $280 \mathrm{~nm}(\mathrm{ND} / 1000 \mathrm{UV} / \mathrm{Vis}$; Thermo Fisher NanoDrop, USA). Two-step real-time RT-PCR was conducted using the CFX Real Time System (BioRad, USA). The reverse transcription (RT) reaction was performed at a final volume of $20 \mu \mathrm{L}$ with $180 \mathrm{ng}$ of RNA (as a cDNA template) using the cDNA reverse transcription kit according to the manufacturer's protocol. Products from the RT reaction were amplified using the FastStart Universal Probe Master (Rox) kit with TaqMan probes as primers for specific genes encoding Actb, Mmp-2, Mmp-9, Timp-1, Timp-2, Timp-3 and Timp-4 according to the manufacturer's protocol. Amplification was carried out in a total volume of $20 \mu \mathrm{L}$ containing $1.5 \mu \mathrm{L}$ of the RT product, and $\beta$-actin was used as the reference gene.

\section{Statistical Analysis}

The data are presented as the means $\pm \mathrm{SD}$ of three independent experiments. Each treatment in experiment was repeated six times $(n=6)$ and measured in triplicate. The average of the triplicate samples was used for the statistical analyses. Statistical analysis was performed on the original results. Considering the different data from the measurement of absorbance, the results were presented as a percentage of controls (LDH and caspase-3 measurements). The data were analysed via one-way analysis of variance (ANOVA) followed by Tukey's multiple comparison procedure in STATISTICA 10 software.

\section{Results}

\section{Impact of VGVAPG on Cell Viability Measurements}

\section{LDH Cell Viability Assay}

After 24 and $48 \mathrm{~h}$ of exposure of primary mouse glial cells to the studied VGVAPG peptide in concentrations ranging from $100 \mathrm{pM}$ to $100 \mu \mathrm{M}$, we observed a lack of stimulation of LDH release (Fig. 1a).

\section{Caspase-3 Activity}

After 24 and $48 \mathrm{~h}$ of exposure of primary mouse glial cells to the studied VGVAPG peptide in concentrations ranging from $100 \mathrm{pM}$ to $100 \mu \mathrm{M}$, we observed a lack of stimulation of caspase-3 activity (Fig. 1b).

\section{Cell Staining}

Primary mouse glial cells were stained with Hoechst 33342 and calcein AM to determine the cell number and to assess their viability and/or metabolic activity. After $24 \mathrm{~h}$ of exposition of the cells to $1 \mu \mathrm{M}$ of the VGVAPG peptide, no changes in the number of cells and their viability in comparison to the control cells were detected (Fig. 2).

\section{Impact of VGVAPG on mRNA Expression Levels in Mouse Cortical Glial Cells}

\section{Expression of $M m p-2$ and $M m p-9$ mRNA}

Primary mouse glial cells were exposed to $50 \mathrm{nM}, 1$ and $50 \mu \mathrm{M}$ of VGVAPG for 3 and $6 \mathrm{~h}$. After $3 \mathrm{~h}$ of exposure to all VGVAPG peptide concentrations, we observed no change in Mmp-2 or Mmp-9 mRNA expression as compared to the control (Fig. 3a). However, after 6 h, there was a decrease in mRNA expression of Mmp- 2 and $M m p-9$ in cells exposed to $50 \mathrm{nM}$ and $1 \mu \mathrm{M}$ of VGVAPG as compared to the control (Mmp-2 mRNA expression decreased by 17.7 and $16.3 \%$ respectively as compared to the control; $M m p-9$ mRNA expression decreased by 33.90 and $44.90 \%$ respectively as compared to the control) (Fig. 3b).

\section{Expression of Timp-1, Timp-2, Timp-3 and Timp-4 mRNA}

After $3 \mathrm{~h}$ of exposure to 1 and $50 \mu \mathrm{M}$ of VGVAPG, a decrease in Timp-1 mRNA expression by 70.20 and $69.20 \%$ was observed as compared to the control. In the same time period, $50 \mathrm{nM}$ and $1 \mu \mathrm{M}$ of VGVAPG decreased Timp-3 mRNA expression by 25.60 and $32.67 \%$, respectively, as compared to the control. Moreover, in cells exposed to 1 and $50 \mu \mathrm{M}$ of VGVAPG, expression of Timp-4 mRNA increased by 140.66 and $147.00 \%$, respectively, as compared to the control (Fig. 4a).

After $6 \mathrm{~h}$ of exposure to $1 \mu \mathrm{M}$ of VGVAPG, no changes in Timp-1 mRNA expression were observed. Moreover, for all of the studied concentrations of VGVAPG $(50 \mathrm{nM}$ and 1 and $50 \mu \mathrm{M}$ ), an increase in Timp-2 mRNA expression by 36.80 , 41.50 and $20.30 \%$, respectively, was observed as compared to the control. Furthermore, concentrations of $50 \mathrm{nM}$ and $1 \mu \mathrm{M}$ of the VGVAPG peptide increased expression of Timp-3 by 22.70 and $26.30 \%$, respectively, as compared to the control. However, $1 \mu \mathrm{M}$ of VGVAPG decreased Timp-4 mRNA expression by 

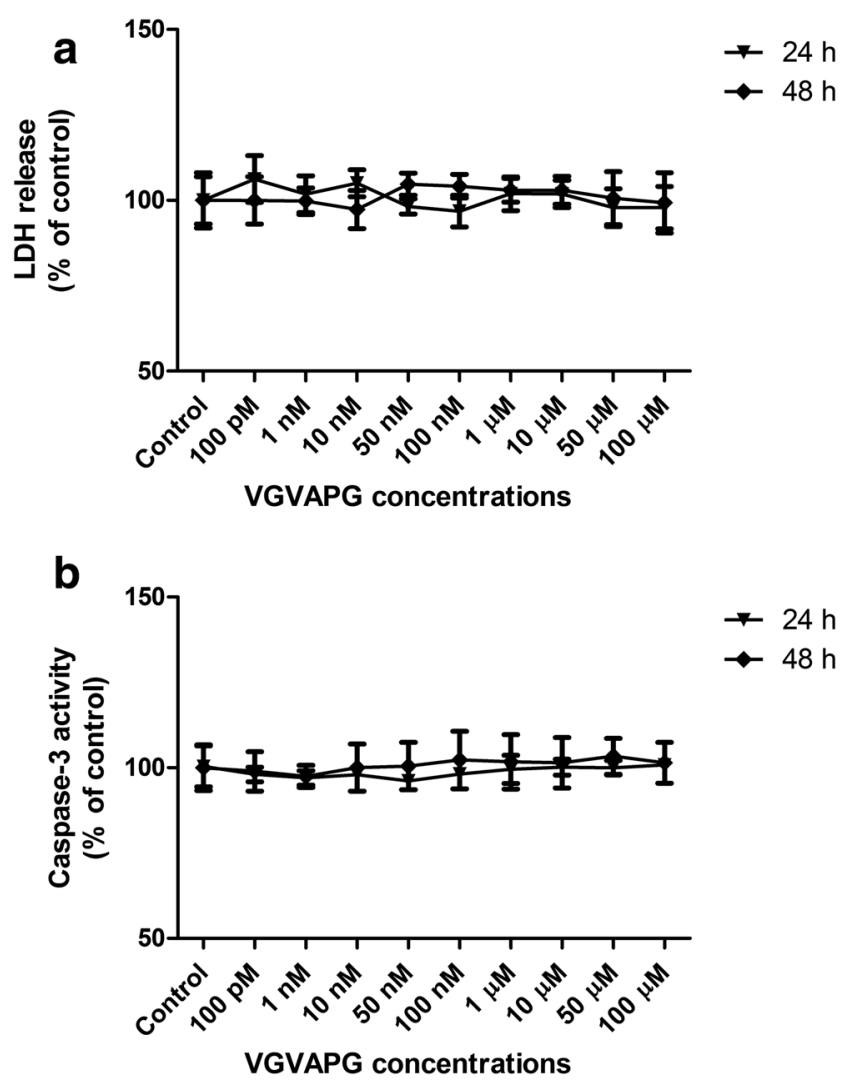

Fig. 1 Effect of the VGVAPG peptide on LDH release (a) and caspase-3 activity (b) after 24 and $48 \mathrm{~h}$ in mouse primary glial cells in vitro. Data are expressed as means \pm SD of three independent experiments, each of which consisted of eight replicates per treatment group

$19.70 \%$ as compared to the control. Interestingly, $50 \mu \mathrm{M}$ of VGVAPG increased Timp- 4 mRNA expression by $22.60 \%$ as compared to the control (Fig. $4 \mathrm{~b}$ ).

\section{Impact of VGVAPG on mRNA Expression Levels After Silencing the Glb1 Gene by siRNA in Mouse Cortical Glial Cells}

After the Glb1 gene silencing procedure, $3 \mathrm{~h}$ of exposure to $1 \mu \mathrm{M}$ of VGVAPG decreased mRNA expression of Mmp-2 and $M m p-9$ (decreased by 77.00 and $37.40 \%$, respectively) as compared to the Glb1 siRNA control. However, the use of Glb1 siRNA alone caused a decrease in the expression of Mmp-9 mRNA as compared to the cells with scramble siRNA (decrease by $27.10 \%$, as compared to the scramble control) (Fig. 5a). After $6 \mathrm{~h}$ of exposure to $1 \mu \mathrm{M}$ of VGVAPG, expression of Mmp-2 and Mmp-9 genes did not change as compared to scramble-siRNA and Glb1-siRNA controls (Fig. 5b).

After the $G l b 1$ gene silencing procedure, $3 \mathrm{~h}$ of exposure to $1 \mu \mathrm{M}$ of VGVAPG decreased mRNA expression of Timp- 1 by $56.80 \%$, as compared to the Glb1-siRNA control. However, the use of Glb1 siRNA alone caused a decrease in the expression of Timp-1 and Timp-4 mRNA as compared to the cells with scramble siRNA (decrease by 20.80 and $20.90 \%$, respectively, as compared to the scramble control) (Fig. 6a). After $6 \mathrm{~h}$ of exposure to $1 \mu \mathrm{M}$ of VGVAPG, a Timp -4 mRNA increase by $91.90 \%$ as compared to the $G l b 1$-siRNA control was observed. However, the use of Glb1 siRNA alone caused a decrease in the expression of Timp- 4 mRNA as compared to the cells with scramble siRNA (decrease by $23.60 \%$, as compared to the scramble control). The expression of Timp-3 mRNA decreased by $26.80 \%$ as compared to scramblesiRNA-treated cells. The expression of Timp-1 and Timp-2 mRNA genes did not change as compared to the scramblesiRNA control (Fig. 6b).

siRNA transfection efficiencies were established by qPCR method. Knockdown of $\mathrm{Glbl}$ gene was estimated at $39 \%$ of the vehicle control mRNA (Fig. 7).

\section{Discussion}

Our study investigated the elastin-derived peptide, VGVAPG, mechanism of action in mouse primary glial cells in vitro. It is known that peptides liberated from a degraded extracellular matrix may interact with different receptors on the cell surface which results in the activation of intracellular signalling pathways which can lead to cellular events as diverse as cell adhesion, migration, proliferation, protein synthesis or apoptosis (Maquart et al. 2004). Due to a lack of data concerning the VGVAPG peptide mechanism of action in CNS, first we investigated its cytotoxic or proapoptotic potential. Our data showed that the VGVAPG peptide was not cytotoxic and did not activate apoptotic cell death in a broad spectrum of concentrations $(100 \mathrm{pM}$ to $100 \mu \mathrm{M})$ and in all of the studied time intervals ( 24 and $48 \mathrm{~h}$ ) in mouse primary glial cells in vitro. A lack of apoptosis is important because the number of EDPs highly increases after a stroke and is accompanied by an inflammation process that can finally lead to cell death (Jin et al. 2010; Nicoloff et al. 2008; Tzvetanov et al. 2008). Moreover, in cells stained with Hoechst 33342 and calcein AM dyes, we observed no changes in the cell morphology and cell viability after $24 \mathrm{~h}$ of exposition of primary glial cells in vitro to $1 \mu \mathrm{M}$ of the VGVAPG peptide.

Our studies are the first to demonstrate that after $3 \mathrm{~h}$ of exposure to $50 \mathrm{nM}, 1$ and $50 \mu \mathrm{M}$ of the VGVAPG peptide, mRNA expression of $\mathrm{Mmp}-2$ and $\mathrm{Mmp}-9$ did not change. After $6 \mathrm{~h}$ of exposure to $50 \mathrm{nM}$ and $1 \mu \mathrm{M}$ of the VGVAPG peptide, Mmp-2 and Mmp-9 mRNA expression decreased as compared to the control level. Interestingly, mRNA expression of both of the studied genes did not change in a concentration of $50 \mu \mathrm{M}$ of VGVAPG. There are no data concerning $M M P-2$ and MMP-9 mRNA expression after stimulation of the VGVAPG peptide in normal cells derived from mouse or human CNS. The available data concerning cancer cells derived from the nervous system show that $100 \mathrm{ng} / \mathrm{mL} \approx$ 
Fig. 2 Effect of the VGVAPG peptide on Hoechst 33342 and calcein AM staining in cultured mouse glial cells in vitro $24 \mathrm{~h}$ post-treatment. a Control cells stained with calcein AM; control cells stained with Hoechst 33342; cells treated with $1 \mu \mathrm{M}$ of the VGVAPG peptide and stained with calcein AM; cells treated with $1 \mu \mathrm{M}$ of the VGVAPG peptide and stained with Hoechst 33342; cells treated with $1 \mu \mathrm{M}$ of staurosporine and stained with calcein AM; cells treated with $1 \mu \mathrm{M}$ of staurosporine and stained with Hoechst 33342. Cells with a light-coloured cytoplasm were identified as live cells. Cells with bright, fragmented nuclei containing condensed chromatin were identified as apoptotic. Photomicrographs are shown at $x$ 200 magnification. b Cell fluorescence in microphotographs was quantified by densitometry in six replications by Image J $1.50 \mathrm{~b}$ a

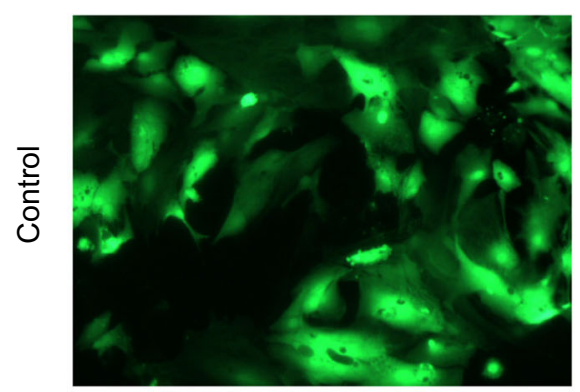

Calcein AM

Hoechst 33342
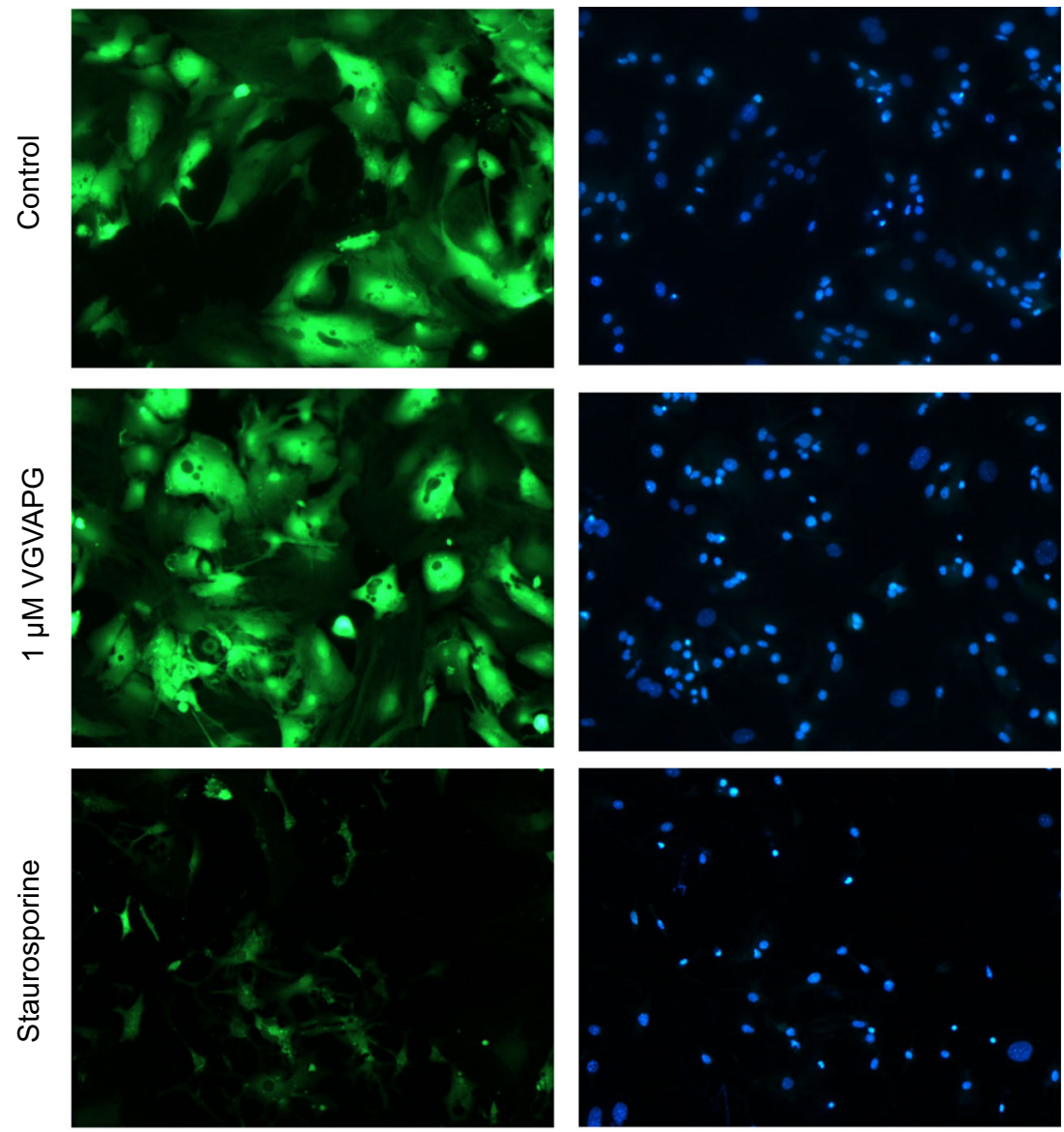

b

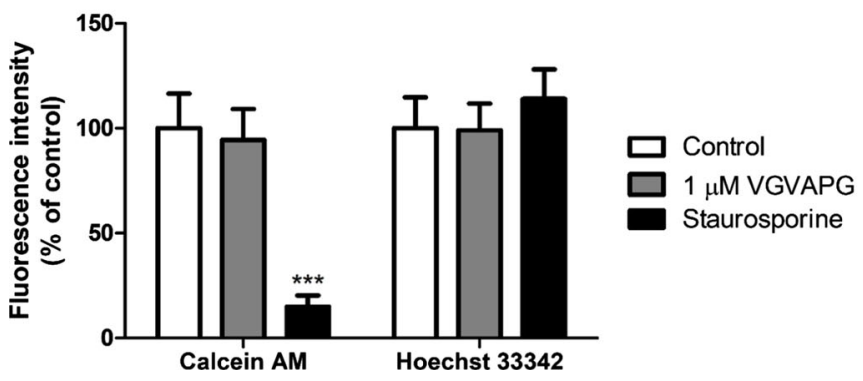

$66.86 \mathrm{nM}$ of the (VGVAPG) ${ }_{3}$ peptide strongly upregulated $M M P-2$ mRNA expression in the rat astrocytoma cell line C6 and human gliomas, such as CB74, CB109 and CB191 (Coquerel et al. 2009). In the same paper, the authors showed a very weak MMP-9 mRNA expression in two of the four studied gliomas. To date, Mmp-2 and Mmp-9 mRNA and protein upregulation by the VGVAPG peptide are well documented in different cell culture models, but mainly in cancerous ones. The discrepancy between our results and mentioned data could be the result of normal and cancer cells differences. The possible mechanism of the decrease in MMP-2 and MMP-9 in glial cells could be connected with nitric oxide
(ON) pathways. There has been shown a link between NO and $M M P-2$ and $M M P-9$ mRNA expression. Such interaction was previously detected in humane endothelial cells in which NO caused the decrease in expression of both $M M P-2$ and MMP-9 mRNA (Chen and Wang 2004; Phillips and Birnby 2004). Moreover, a similar association has been shown in rat primary astrocytes, where downregulation of $M m p-9$ mRNA levels was caused by NO (Shin et al. 2007). It is known that the VGVAPG peptide has high affinity to EBP (Devy et al. 2010; Robinet 2005; Senior et al. 1984). Therefore, we decided to use specific siRNA targeting in the Glbl gene which is alternatively spliced in EBP. In glial cells with Glbl gene 

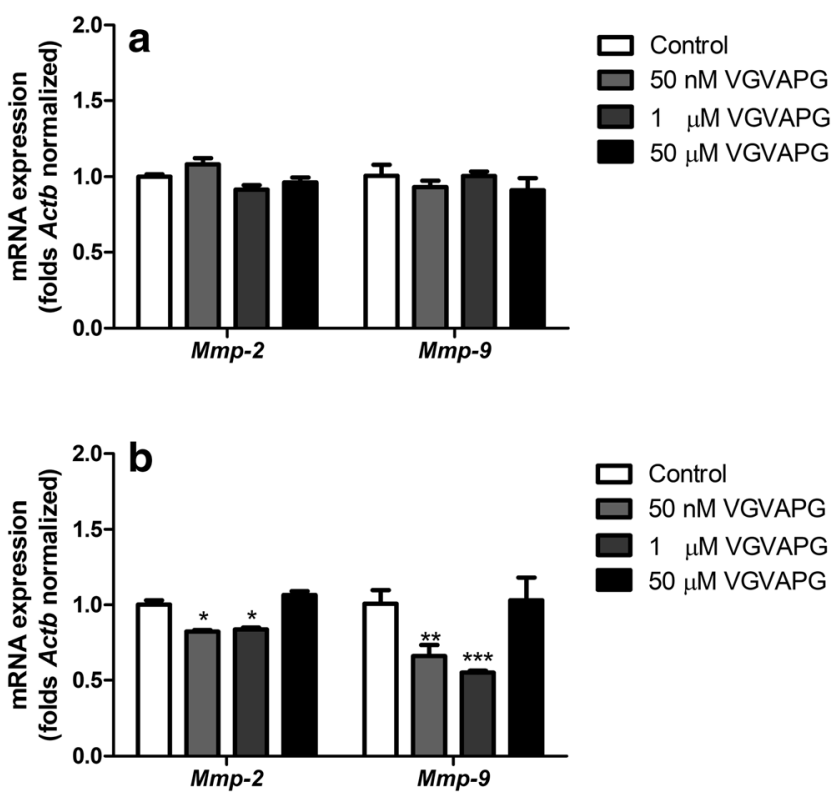

Fig. 3 Effect of $50 \mathrm{nM}, 1$ and $50 \mu \mathrm{M}$ of the VGVAPG peptide on mRNA expression of Mmp-2 and Mmp-9 after $3 \mathrm{~h}$ (a) and $6 \mathrm{~h}$ (b) of exposure. mRNA expression was normalised to Actb. Data are expressed as means $\pm \mathrm{SD}$ of three independent experiments, each of which consisted of six replicates per treatment group; $* P<0.05$; $* * P<0.01$; $* * * P<0.001$ vs. the vehicle control

knockdown, $3 \mathrm{~h}$ of exposure to VGVAPG decreased Mmp-2 and $M m p-9$ mRNA expression. The obtained data suggest that Mmp-2 and Mmp-9 mRNA expression can be partially dependent on EBP activation.
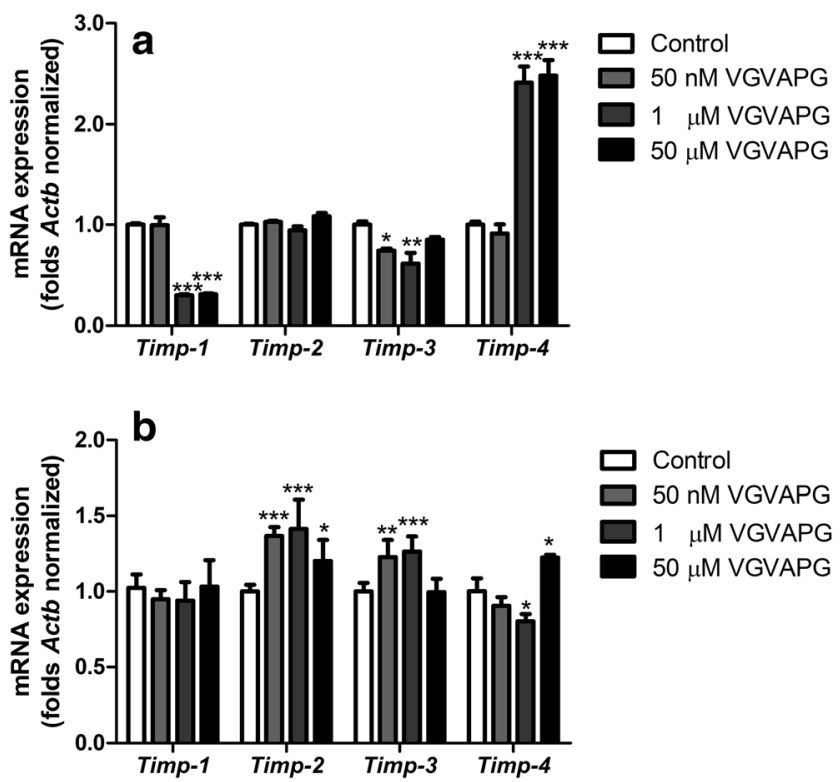

Fig. 4 Effect of $50 \mathrm{nM}, 1$ and $50 \mu \mathrm{M}$ of the VGVAPG peptide on mRNA expression of Timp-1, Timp-2, Timp-3 and Timp-4 after $3 \mathrm{~h}$ (a) and $6 \mathrm{~h}$ (b) of exposure. mRNA expression was normalised to Actb. Data are expressed as means $\pm \mathrm{SD}$ of three independent experiments, each of which consisted of six replicates per treatment group; $* P<0.05$; $* * P<$ $0.01 ; * * * P<0.001$ vs. the vehicle control
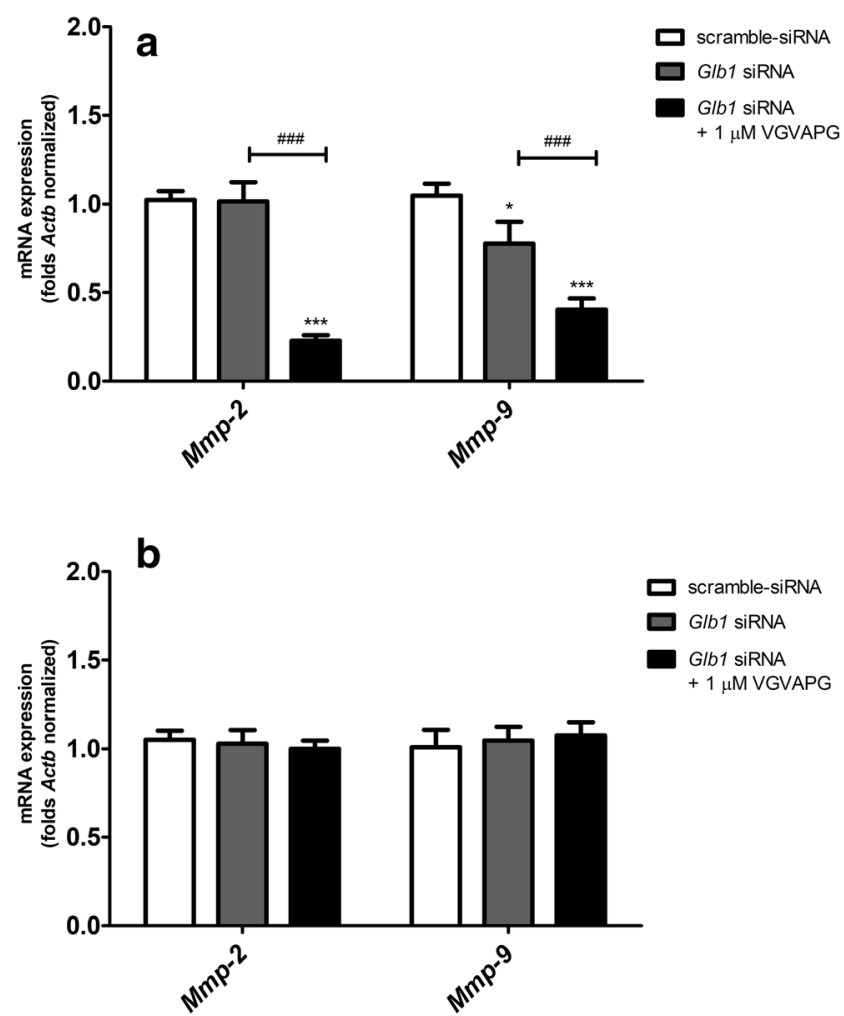

Fig. 5 Effect of $1 \mu \mathrm{M}$ of the VGVAPG peptide on mRNA expression of Mmp- 2 and Mmp-9 after $3 \mathrm{~h}$ (a) and $6 \mathrm{~h}$ (b) of exposure. The experiment contains control with scramble-siRNA and control with Glbl-siRNA. The experiment was conducted $12 \mathrm{~h}$ after Glbl gene silencing by siRNA. mRNA expression was normalised to Actb. Data are expressed as means $\pm \mathrm{SD}$ of three independent experiments, each of which consisted of six replicates per treatment group; $* P<0.05$; $* * * P<0.001$ vs. scramble-siRNA control; ${ }^{\# \#} P<0.001$ vs. Glb1-siRNA control

After secretion from producing cells, MMP activity can be regulated by TIMPs (Kurzepa et al. 2014). TIMP-1 inhibits most of the MMPs with the highest affinity to MMP-9, but TIMP-2 and TIMP-4 have the highest affinity to MMP-2 (Brew et al. 2000; Trojanek 2015). TIMP-3 is different than the other TIMPs, as it is insoluble, attached to the extracellular matrix (ECM) and inhibits disintegrin and metalloproteinase (ADAMs) with high affinity (Crocker et al. 2004). However, TIMPs also perform other physiological functions. TIMP-1 and TIMP-2 are responsible for such functions as induction of erythropoiesis, mitogenesis and apoptosis (Docherty et al. 1985; Guedez et al. 1998b; Stetler-Stevenson et al. 1992). Moreover, astrocytic Timp-1 promotes oligodendrocyte differentiation and enhances myelination in CNS (Moore et al. 2011). TIMP-2 inhibits endothelial cell growth induced by fibroblast growth factor (Ahonen et al. 2003; Lipka and Boratyński 2008). TIMP-3 also shows proapoptotic properties due to stabilisation of the Fas receptor (FasR), while TIMP-1 and TIMP-2 can also exhibit anti-apoptotic properties (Cawston and Mercer 1986; Guedez et al. 1998a). Moreover, an increase in mRNA expression of both Timp-2 and Timp-3 has been observed in places of increased neurogenesis, cell 

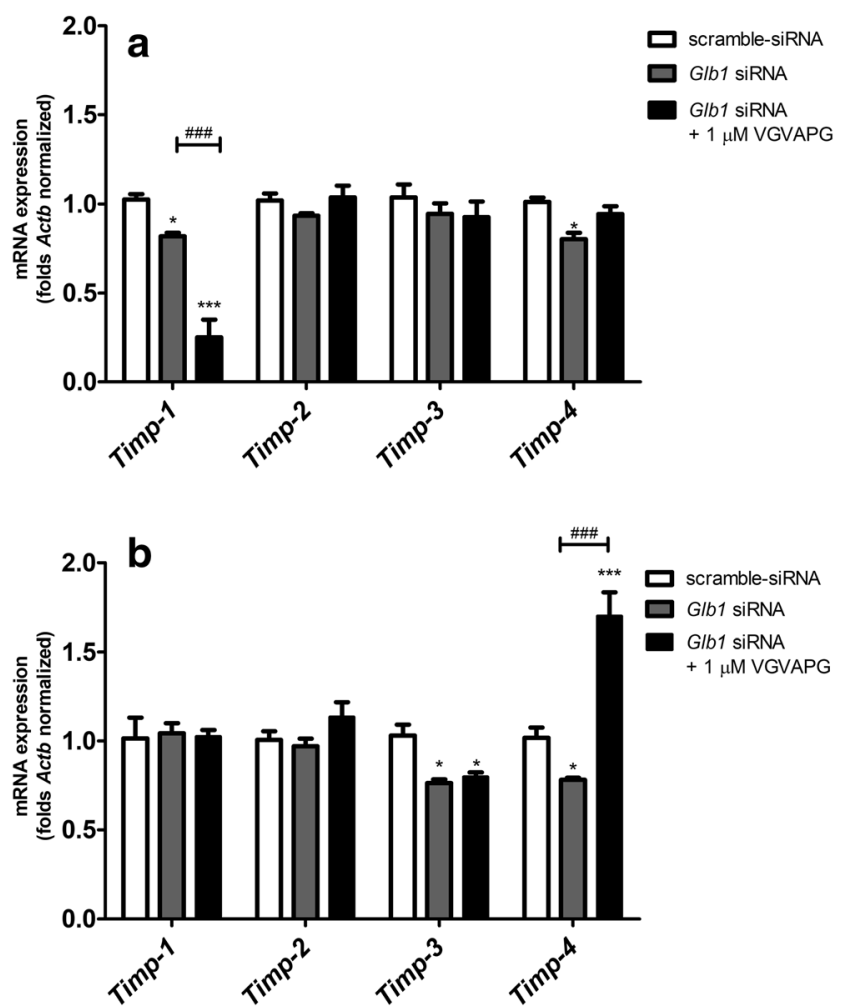

Fig. 6 Effect of $1 \mu \mathrm{M}$ of the VGVAPG peptide on mRNA expression of Timp-1, Timp-2, Timp-3 and Timp-4 after $3 \mathrm{~h}$ (a) and $6 \mathrm{~h}$ (b) of exposure. The experiment contains control with scramble-siRNA and control with Glb1-siRNA. The experiment was conducted $12 \mathrm{~h}$ after $G l b 1$ gene silencing by siRNA. mRNA expression was normalised to Actb. Data are expressed as means $\pm \mathrm{SD}$ of three independent experiments, each of which consisted of six replicates per treatment group; $* P<0.05 ; * * * P$ $<0.001$ vs. scramble-siRNA control; ${ }^{\# \# \#} P<0.001$ vs. Glb1-siRNA control

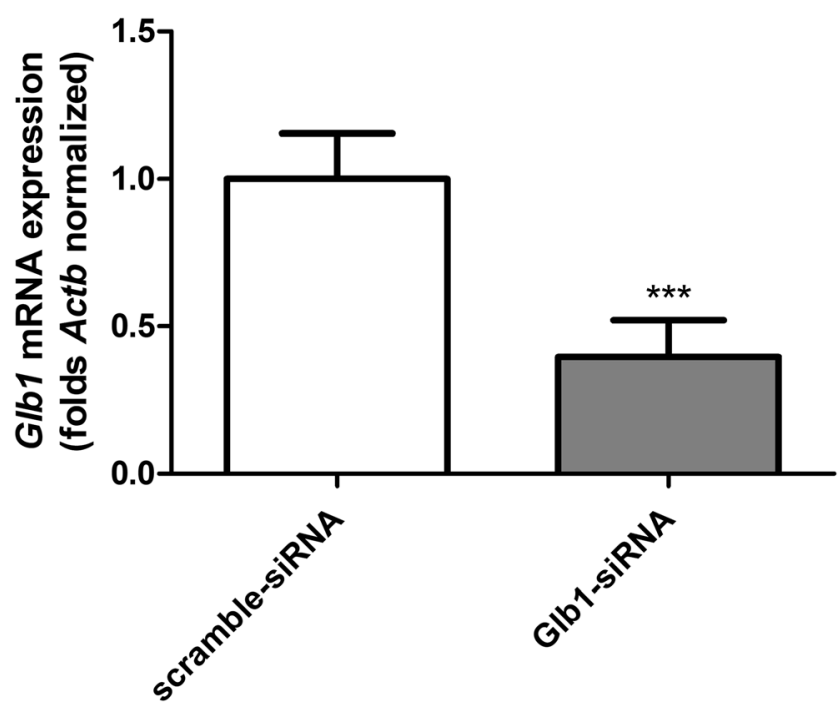

Fig. 7 Effect of Glb1 gene silencing by siRNA on Glb1 gene mRNA expression. mRNA expression was normalised to Actb. Data are expressed as means $\pm \mathrm{SD}$ of three independent experiments, each of which consisted of six replicates per treatment group; $* * * P<0.001 \mathrm{vs.}$ the vehicle control maturation and migration (Jaworski and Fager 2000; Vaillant et al. 1999). To date, the role of TIMP-4 continues to be poorly understood, although it has been shown that TIMP-4 activated apoptosis of fibroblasts from cardiac muscle and inhibited migration of cells capable of forming capillaries, while there was no impact on the process of proliferation and angiogenesis (Koskivirta et al. 2006).

Our data are the first to show that after $3 \mathrm{~h}$ of exposure to 1 and $50 \mu \mathrm{M}$ of the VGVAPG peptide, Timp-1 mRNA expression in glial cells was significantly decreased. However, after $6 \mathrm{~h}$ of exposure to 1 and $50 \mu \mathrm{M}$ of the VGVAPG peptide, the Timp-1 mRNA expression pattern did not change as compared to the control. Silencing of the Glb1 gene did not change the Timp-1 mRNA expression pattern caused by $1 \mu \mathrm{M}$ of the VGVAPG peptide. Such data suggest that in Timp-1, mRNA expression is regulated by an EBP-independent mechanism. To date, it has been shown that after birth in the rat brain, Timp-1 mRNA expression significantly decreased (Fager and Jaworski 2000). Similarly, downregulation of Timp-1 mRNA and protein expression was observed in Sprague Dawley rats with ischemic-reperfusion (Ma et al. 2016). In patients with end-stage neurological disease, chronic activation of astrocytes by IL- $1 \beta$ caused downregulation of TIMP-1 mRNA and protein expression in CSF and brain tissues (Gardner and Ghorpade 2003).

In our experiments, Timp-2 and Timp-3 mRNA expression significantly increased after $6 \mathrm{~h}$ of exposure to $50 \mathrm{nM}$ and $1 \mu \mathrm{M}$ of the VGVAPG peptide. However, knockout of the Glb1 gene abolished the effects of $1 \mu \mathrm{M}$ of VGVAPG peptide action. Our data would suggest that activation of Timp-2 and Timp-3 mRNA expression is mainly EBP-dependent. To date, it has been reported that increased expression of TIMP-3 enhances Fas-mediated cell death through stabilisation of the FasR as well as by preventing shedding of FasL from the extracellular matrix (Ahonen et al. 2003; Mitsiades et al. 1998). Furthermore, it has also been demonstrated that integrin $\alpha 3 \beta 1$ as a TIMP-2 receptor results in inhibition of fibroblast growth factor (FGF) or VEGF-induced angiogenesis by effectively blocking the association of HSP60 and SHP-1 to this receptor (Seo et al. 2003). High mRNA expression of Timp-2 and Timp3 was detected in zones of neurogenesis in rat brains and these proteins are considered important in cellular proliferation and/ or differentiation (Jaworski and Fager 2000; Vaillant et al. 1999). Furthermore, enhanced TIMP-3 mRNA expression was found in normal human proliferating keratinocytes during the wound healing process (Vaalamo et al. 1999). It has also been shown that TIMP-3 possesses growth factor-like properties and its presence is required for the growth of oligodendrocytes (Gomez et al. 1997; Oh et al. 1999).

After $3 \mathrm{~h}$ of exposure to 1 and $50 \mu \mathrm{M}$ of VGVAPG peptide, Timp-4 mRNA expression significantly increased; however, after $6 \mathrm{~h}$ of exposure to $50 \mathrm{nM}$ and $1 \mu \mathrm{M}$ of VGVAPG peptide, Timp-4 mRNA expression decreased. Silencing the Glb1 gene 
protected the cells against changes caused by $1 \mu \mathrm{M}$ of VGVAPG peptide in Timp-4 mRNA expression after $3 \mathrm{~h}$; however, after $6 \mathrm{~h}$, mRNA expression of Timp-4 significantly increased. Our data suggest that Timp-4 mRNA expression can be partially EDP-dependent. TIMP-4 has been poorly studied and data concerning its expression and function are limited. To date, it has been shown that TIMP-4 expression increases during damage of blood vessels and is correlated with a developing inflammation (Koskivirta et al. 2006). Moreover, upregulation of TIMP-4 in response to inflammation in CSF from patients with tropical spastic paraparesis or myelopathy associated with $\mathrm{T}$ cell lymphotropic virus was observed (Kettlun et al. 2003). Research conducted on human gliomas has shown that TIMP-4 substantially reduced glioma's invasive capacity, although without decreased cell viability and proliferation (Groft et al. 2001). Currently, it is believed that TIMP-4 mRNA and protein upregulation appear in a pathological inflammation where extracellular matrix remodeling is usually induced and in the wound repair process (Koskivirta et al. 2006; Vaalamo et al. 1999).

Interestingly, Fager and Jaworski (2000) studied mRNA expression of Timp-1, Timp-2, Timp-3 and Timp-4 during rat central nervous system development. They showed that in whole-brain extracts, Timp-1 mRNA slowly disappeared in favour of gradually increasing Timp-4. Furthermore, Timp-2 and Timp-3 mRNA slowly grew throughout the rat's entire lifespan. The whole Timp mRNA expression pattern obtained in our study is consistent with that previously found by Fager and Jaworski (2000) during development of CNS.

\section{Conclusion}

Our study is the first to have investigated the VGVAPG mechanism of action in mouse primary glial cells in vitro. Our experiments show that VGVAPG in a wide range of concentrations exhibits neither cytotoxic nor proapoptotic properties in mouse glial cells. Our research shows that an increase in mRNA expression of Timp-2 and Timp-3 genes in mouse glial cells in vitro is EBP-dependent. Nevertheless, changes in mRNA expression of Mmp-2, Mmp-9 and Timp-4 genes in mouse glial cells in vitro can be partially EBP-dependent. Decreased mRNA expression of Timp-1 is probably EBP-independent. Our data suggest that VGVAPG peptides sensitise mouse glial cells in vitro to apoptotic or pro-inflammatory signals from the brain microenvironment. However, we cannot exclude that the increasing expression of Timp-2, Timp-3 and Timp- 4 mRNA also facilitates brain repair after a stroke by increasing cell proliferation and/or differentiation. Our research is pioneering in this research field and has a preliminary character; further studies underlying VGVAPG peptide mechanisms of action in the nervous system are thus necessary.
Funding Information This work was supported by statutory funds from the University of Information Technology and Management in Rzeszow, Poland (DS 503-07-02-21).

\section{Compliance with Ethical Standards}

All procedures were approved by a Bioethics Commission (no. 46/2014, First Local Ethical Committee on Animal Testing at the Jagiellonian University in Krakow), as compliant with European Union law.

Open Access This article is distributed under the terms of the Creative Commons Attribution 4.0 International License (http:// creativecommons.org/licenses/by/4.0/), which permits unrestricted use, distribution, and reproduction in any medium, provided you give appropriate credit to the original author(s) and the source, provide a link to the Creative Commons license, and indicate if changes were made.

\section{References}

Agrawal SM, Lau L, Yong VW (2008) MMPs in the central nervous system: where the good guys go bad. Semin Cell Dev Biol 19:4251. https://doi.org/10.1016/j.semcdb.2007.06.003

Ahonen M, Poukkula M, Baker AH, Kashiwagi M, Nagase H, Eriksson JE, Kähäri V-M (2003) Tissue inhibitor of metalloproteinases-3 induces apoptosis in melanoma cells by stabilization of death receptors. Oncogene 22:2121-2134. https://doi.org/10.1038/sj.onc. 1206292

Blomstrand F, Giaume C (2006) Kinetics of endothelin-induced inhibition and glucose permeability of astrocyte gap junctions. J Neurosci Res 83:996-1003. https://doi.org/10.1002/jnr.20801

Blood CH, Sasse J, Brodt P, Zetter BR (1988) Identification of a tumor cell receptor for VGVAPG, an elastin-derived chemotactic peptide. J Cell Biol 107:1987-1993. https://doi.org/10.1083/jcb.107.5.1987

Brassart B, Randoux A, Hornebeck W, Emonard H (1998) Regulation of matrix metalloproteinase-2 (gelatinase A, MMP-2), membrane-type matrix metalloproteinase-1 (MT1-MMP) and tissue inhibitor of metalloproteinases-2 (TIMP-2) expression by elastin-derived peptides in human HT-1080 fibrosarcoma cell line. Clin Exp Metastasis 16:489-500. https://doi.org/10.1023/A:1006550503612

Brew K, Dinakarpandian D, Nagase H (2000) Tissue inhibitors of metalloproteinases: evolution, structure and function. Biochim Biophys Acta Protein Struct Mol Enzymol 1477:267-283. https://doi.org/10. 1016/S0167-4838(99)00279-4

Cawston TE, Mercer E (1986) Preferential binding of collagenase to alpha 2-macroglobulin in the presence of the tissue inhibitor of metalloproteinases. FEBS Lett 209:9-12. https://doi.org/10.1016/ 0014-5793(86)81074-2

Chang CH, Kawa Y, Tsai RK, Shieh JH, Lee JW, Watabe H, Kawakami T, Soma Y, Tajima S, Mizoguchi M (2008) Melanocyte precursors express elastin binding protein and elastin-derived peptide (VGVAPG) stimulates their melanogenesis and dendrite formation. J Dermatol Sci 51:158-170. https://doi.org/10.1016/j.jdermsci. 2008.03.010

Chen HH, Wang DL (2004) Nitric oxide inhibits matrix metalloproteinase- 2 expression via the induction of activating transcription factor 3 in endothelial cells. Mol Pharmacol 65:1130 1140. https://doi.org/10.1124/mol.65.5.1130\r65/5/1130

Coquerel B, Poyer F, Torossian F, Dulong V, Bellon G, Dubus I, Reber A, Vannier JP (2009) Elastin-derived peptides: matrikines critical for glioblastoma cell aggressiveness in a 3-D system. Glia 57:17161726. https://doi.org/10.1002/glia.20884 
Crocker SJ, Pagenstecher A, Campbell IL (2004) The TIMPs tango with MMPs and more in the central nervous system. J Neurosci Res 75: 1-11. https://doi.org/10.1002/jnr.10836

Cunningham LA, Wetzel M, Rosenberg GA (2005) Multiple roles for MMPs and TIMPs in cerebral ischemia. Glia 50:329-339. https:// doi.org/10.1002/glia.20169

Devy J, Duca L, Cantarelli B, Joseph-Pietras D, Scandolera A, Rusciani A, Parent L, Thevenard J, Pasco SB, Tarpin M, Martiny L, Debelle L (2010) Elastin-derived peptides enhance melanoma growth in vivo by upregulating the activation of Mcol-A (MMP-1) collagenase. $\mathrm{Br}$ J Cancer 103:1562-1570. https://doi.org/10.1038/sj.bjc.6605926

Docherty AJP, Lyons A, Smith BJ, Wright EM, Stephens PE, Harris TJR, Murphy G, Reynolds JJ (1985) Sequence of human tissue inhibitor of metalloproteinases and its identity to erythroid-potentiating activity. Nature 318:66-69. https://doi.org/10.1038/318066a0

Donet M, Brassart-Pasco S, Salesse S, Maquart F-X, Brassart B (2014) Elastin peptides regulate HT-1080 fibrosarcoma cell migration and invasion through an Hsp90-dependent mechanism. Br J Cancer 111: 139-148. https://doi.org/10.1038/bjc.2014.239

Fager N, Jaworski DM (2000) Differential spatial distribution and temporal regulation of tissue inhibitor of metalloproteinase mRNA expression during rat central nervous system development. Mech Dev 98:105-109

Floquet N, Héry-Huynh S, Dauchez M, Derreumaux P, Tamburro AM, Alix AJP (2004) Structural characterization of VGVAPG, an elastinderived peptide. Biopolymers 76:266-280. https://doi.org/10.1002/ bip. 20029

Gardner J, Ghorpade A (2003) Tissue inhibitor of metalloproteinase (TIMP)-1: the TIMPed balance of matrix metalloproteinases in the central nervous system. J Neurosci Res 74:801-806. https://doi.org/ 10.1002/jnr.10835

Gmiński J, Mykała-Cieśla J, Machalski M, Dróżdż M (1992) Anti-elastin antibodies in patients with lung cancer. Immunol Lett 33:211-215. https://doi.org/10.1016/0165-2478(92)90049-T

Gmiński J, Mykała-Cieśla J, Machalski M, Dróżdż M (1993) Elastin metabolism parameters in sera of patients with lung cancer. Neoplasma 40:41-44

Gomez DE, Alonso DF, Yoshiji H, Thorgeirsson UP (1997) Tissue inhibitors of metalloproteinases: structure, regulation and biological functions. Eur J Cell Biol 74:111-122

Groft LL, Muzik H, Rewcastle NB, Johnston RN, Knäuper V, Lafleur MA, Forsyth PA, Edwards DR (2001) Differential expression and localization of TIMP-1 and TIMP-4 in human gliomas. Br J Cancer 85:55-63. https://doi.org/10.1054/bjoc.2001.1854

Guedez L, Courtemanch L, Stetler-Stevenson M (1998a) Tissue inhibitor of metalloproteinase (TIMP)-1 induces differentiation and an antiapoptotic phenotype in germinal center B cells. Blood 92: 1342-1349

Guedez L, Stetler-Stevenson WG, Wolff L, Wang J, Fukushima P, Mansoor A, Stetler-Stevenson M (1998b) In vitro suppression of programmed cell death of B cells by tissue inhibitor of metalloproteinases-1. J Clin Invest 102:2002-2010. https://doi.org/10.1172/ JCI2881

Hinek A, Rabinovitch M, Keeley F, Okamura-Oho Y, Callahan J (1993) The $67-\mathrm{kD}$ elastin/laminin-binding protein is related to an enzymatically inactive, alternatively spliced form of beta-galactosidase. J Clin Invest 91:1198-1205. https://doi.org/10.1172/JCI116280

Jaworski DM, Fager N (2000) Regulation of tissue inhibitor of metalloproteinase-3 (Timp-3) mRNA expression during rat CNS development. J Neurosci Res 61:396-408. https://doi.org/10.1002/ 1097-4547(20000815)61

Jin R, Yang G, Li G (2010) Inflammatory mechanisms in ischemic stroke: role of inflammatory cells. J Leukoc Biol 87:779-789. https://doi. org/10.1189/jlb.1109766

Jung S, Rutka JT, Hinek A (1998) Tropoelastin and elastin degradation products promote proliferation of human astrocytoma cell lines. $\mathrm{J}$
Neuropathol Exp Neurol 57:439-448. https://doi.org/10.1097/ 00005072-199805000-00007

Kettlun AM, Cartier L, García L, Collados L, Vásquez F, Ramírez E, Valenzuela MA (2003) TIMPs and MMPs expression in CSF from patients with TSP/HAM. Life Sci 72:2863-2876. https://doi.org/10. 1016/S0024-3205(03)00146-2

Koh JY, Choi DW (1987) Quantitative determination of glutamate mediated cortical neuronal injury in cell culture by lactate dehydrogenase efflux assay. J Neurosci Methods 20:83-90. https://doi.org/10.1016/ 0165-0270(87)90041-0

Koskivirta I, Rahkonen O, Mäyränpää M, Pakkanen S, Husheem M, Sainio A, Hakovirta H, Laine J, Jokinen E, Vuorio E, Kovanen P, Järveläinen H (2006) Tissue inhibitor of metalloproteinases 4 (TIMP4) is involved in inflammatory processes of human cardiovascular pathology. Histochem Cell Biol 126:335-342. https://doi. org/10.1007/s00418-006-0163-8

Kurzepa J, Kurzepa J, Golab P, Czerska S, Bielewicz J (2014) The significance of matrix metalloproteinase (MMP)-2 and MMP-9 in the ischemic stroke. Int J Neurosci 124:707-716. https://doi.org/10. 3109/00207454.2013.872102

Lipka D, Boratyński J (2008) Metaloproteinazy MMP. Struktura i funkcja Postepy Hig Med Dosw 62:328-336

Lombard C, Arzel L, Bouchu D, Wallach J, Saulnier J (2006) Human leukocyte elastase hydrolysis of peptides derived from human elastin exon 24. Biochimie 88:1915-1921. https://doi.org/10.1016/j. biochi.2006.07.014

Ma R, Yuan B, Du J, Wang L, Ma L, Liu S, Shu Q, Sun H (2016) Electroacupuncture alleviates nerve injury after cerebra ischemia in rats through inhibiting cell apoptosis and changing the balance of MMP-9/TIMP-1 expression. Neurosci Lett 633:158-164. https:// doi.org/10.1016/j.neulet.2016.09.033

Maquart FX, Pasco S, Ramont L, Hornebeck W, Monboisse JC (2004) An introduction to matrikines: extracellular matrix-derived peptides which regulate cell activity - implication in tumor invasion. Crit Rev Oncol Hematol 49:199-202. https://doi.org/10.1016/j.critrevonc. 2003.06.007

Mitsiades N, Poulaki V, Kotoula V, Leone A, Tsokos M (1998) Fas ligand is present in tumors of the Ewing's sarcoma family and is cleaved into a soluble form by a metalloproteinase. Am J Pathol 153:19471956. https://doi.org/10.1016/S0002-9440(10)65708-2

Moore CS, Milner R, Nishiyama A, Frausto RF, Serwanski DR, Pagarigan RR, Whitton JL, Miller RH, Crocker SJ (2011) Astrocytic tissue inhibitor of metalloproteinase-1 (TIMP-1) promotes oligodendrocyte differentiation and enhances CNS myelination. J Neurosci 31:6247-6254. https://doi.org/10.1523/ JNEUROSCI.5474-10.2011

Nicholson DW, Ali A, Thornberry NA, Vaillancourt JP, Ding CK, Gallant M, Gareau Y, Griffin PR, Labelle M, Lazebnik YA (1995) Identification and inhibition of the ICE/CED-3 protease necessary for mammalian apoptosis. Nature 376:37-43. https://doi.org/10. $1038 / 376037 \mathrm{a} 0$

Nicoloff G, Tzvetanov P, Christova P, Baydanoff S (2008) Detection of elastin derived peptides in cerebrospinal fluid of patients with first ever ischaemic stroke. Neuropeptides 42:277-282. https://doi.org/ 10.1016/j.npep.2008.02.003

Ntayi C, Labrousse AL, Debret R, Birembaut P, Bellon G, Antonicelli F, Hornebeck W, Bernard P (2004) Elastin-derived peptides upregulate matrix metalloproteinase-2-ediated melanoma cell invasion through elastin-binding protein. J Investig Dermatol 122:256-265. https:// doi.org/10.1046/j.0022-202X.2004.22228.x

O'Rourke MF (2007) Arterial aging: pathophysiological principles. Vasc Med 12:329-341. https://doi.org/10.1177/1358863X07083392

Oh LY, Larsen PH, Krekoski CA, Edwards DR, Donovan F, Werb Z, Yong VW (1999) Matrix metalloproteinase-9/gelatinase B is required for process outgrowth by oligodendrocytes. J Neurosci 19: 8464-8475 
Phillips PG, Birnby LM (2004) Nitric oxide modulates caveolin-1 and matrix metalloproteinase- 9 expression and distribution at the endothelial cell/tumor cell interface. Am J Physiol Lung Cell Mol Phys 286:L1055-L1065. https://doi.org/10.1152/ajplung.00262.2003

Pocza P, Süli-Vargha H, Darvas Z, Falus A (2008) Locally generated VGVAPG and VAPG elastin-derived peptides amplify melanoma invasion via the galectin-3 receptor. Int J Cancer 122:1972-1980. https://doi.org/10.1002/ijc.23296

Robinet A (2005) Elastin-derived peptides enhance angiogenesis by promoting endothelial cell migration and tubulogenesis through upregulation of MT1-MMP. J Cell Sci 118:343-356. https://doi.org/10. $1242 /$ jcs. 01613

Saura J (2007) Microglial cells in astroglial cultures: a cautionary note. J Neuroinflammation 4:26. https://doi.org/10.1186/1742-2094-4-26

Senior RM, Griffin GL, Mecham RP, Wrenn DS, Prasad KU, Urry DW (1984) Val-Gly-Val-Ala-Pro-Gly, a repeating peptide in elastin, is chemotactic for fibroblasts and monocytes. J Cell Biol 99:870 874. https://doi.org/10.1083/jcb.99.3.870

Seo D-W, Li H, Guedez L, Wingfield PT, Diaz T, Salloum R, Wei B, Stetler-Stevenson WG (2003) TIMP-2 mediated inhibition of angiogenesis. Cell 114:171-180. https://doi.org/10.1016/S0092-8674(03) 00551-8

Shin CY, Lee WJ, Choi JW, Choi MS, Ryu JR, Oh SJ, Cheong JH, Choi EY, Ko KH (2007) Down-regulation of matrix metalloproteinase-9 expression by nitric oxide in lipopolysaccharide-stimulated rat primary astrocytes. Nitric Oxide 16:425-432. https://doi.org/10.1016/j. niox.2007.03.004

Siemianowicz K, Gminski J, Goss M, Francuz T, Likus W, Jurczak T, Garczorz W (2010) Influence of elastin-derived peptides on metalloprotease production in endothelial cells. Exp Ther Med 1: 1057-1060. https://doi.org/10.3892/etm.2010.157

Skeie JM, Hernandez J, Hinek A, Mullins RF (2012) Molecular responses of choroidal endothelial cells to elastin derived peptides through the elastin-binding protein (GLB1). Matrix Biol 31:113119. https://doi.org/10.1016/j.matbio.2011.11.003

Stetler-Stevenson WG, Bersch N, Golde DW (1992) Tissue inhibitor of metalloproteinase-2 (TIMP-2) has erythroid-potentiating activity. FEBS Lett 296:231-234

Szychowski KA, Sitarz AM, Wojtowicz AK (2015) Triclosan induces Fas receptor-dependent apoptosis in mouse neocortical neurons in vitro. Neuroscience 284:192-201. https://doi.org/10.1016/j. neuroscience.2014.10.001

Szychowski KA, Leja ML, Kaminskyy DV, Kryshchyshyn AP, Binduga UE, Pinyazhko OR, Lesyk RB, Tobiasz J, Gmiński J (2017) Anticancer properties of 4-thiazolidinone derivatives depend on peroxisome proliferator-activated receptor gamma (PPAR $\gamma$ ). Eur J Med Chem 141:162-168. https://doi.org/10.1016/j.ejmech.2017.09.071

Trojanek JB (2015) Role of matrix metalloproteinases and tissue inhibitors of metalloproteinases in hypertension. Pathogenesis of hypertension and obesity. Postepy Biochem 61:356-363

Tzvetanov P, Nicoloff G, Rousseff R, Christova P (2008) Increased levels of elastin-derived peptides in cerebrospinal fluid of patients with lacunar stroke. Clin Neurol Neurosurg 110:239-244. https://doi. org/10.1016/j.clineuro.2007.11.003

Vaalamo M, Leivo T, Saarialho-Kere U (1999) Differential expression of tissue inhibitors of metalloproteinases (TIMP-1, -2, -3, and -4) in normal and aberrant wound healing. Hum Pathol 30:795-802

Vaillant C, Didier-Bazès M, Hutter A, Belin MF, Thomasset N (1999) Spatiotemporal expression patterns of metalloproteinases and their inhibitors in the postnatal developing rat cerebellum. J Neurosci 19: 4994-5004

Vanmeter TE, Rooprai HK, Kibble MM, Fillmore HL, Broaddus WC, Pilkington GJ (2001) The role of matrix metalloproteinase genes in glioma invasion: co-dependent and interactive proteolysis. J NeuroOncol 53:213-235. https://doi.org/10.1023/A:1012280925031

Vitvitsky V, Thomas M, Ghorpade A, Gendelman HE, Banerjee R (2006) A functional transsulfuration pathway in the brain links to glutathione homeostasis. J Biol Chem 281:35785-35793. https://doi.org/10. 1074/jbc.M602799200

Wang JY, Shum AY, Hwang CP (1998) Ethanol modulates induction of nitric oxide synthase in glial cells by endotoxin. Life Sci 63:15711583

Wang XX, Tan MS, Yu JT, Tan L (2014) Matrix metalloproteinases and their multiple roles in Alzheimer's disease. Biomed Res Int 2014: 908636. https://doi.org/10.1155/2014/908636

Yong VW, Power C, Forsyth P, Edwards DR (2001) Metalloproteinases in biology and pathology of the nervous system. Nat Rev Neurosci 2:502-511. https://doi.org/10.1038/35081571 